\title{
Технологии возделывания топинамбура
}

\author{
Н.Н. Романюк ${ }^{1}$, К.В. Сашко, А.В. Горный, К.Г. Романюк \\ Белорусский государственный аграрный технический университет \\ (2. Минск, Республика Беларусь) e-mail: ${ }^{1}$ romanyuk-nik@tut.by
}

\begin{abstract}
В статье проанализированы технологии возделывания топинамбура в Республике Беларусь и Российской Федерации. Топинамбур долгие годы рассматривался как кормовая культура, однако анализ результатов последних научных исследований показал, что это культура комплексного использования. Прежде всего - это ценное пищевое растение. Благодаря уникальному биохимическому составу клубней, сухой порошок из них является хорошей биологически активной добавкой во многие продукты питания.

Топинамбур является также ценным сырьем для технической переработки и производства биоэтанола. Общепринятая технология возделывания топинамбура на гребнях с междурядьями 70 см не всегда обеспечивает нормальные условия для его роста и развития из за узких междурядий, не позволяющих обеспечить необходимое питание растений. В исследованиях, проведенных В.И. Старовойтовым, установлено, что общепринятая технология возделывания топинамбура на гребнях с междурядьями 70 (75) см не обеспечивает нормальные условия для роста и развития топинамбура, особенно во влажные годы, что приводит к снижению урожая или полной его гибели. С их точки зрения для топинамбура наиболее перспективно использование грядовой технологии с шириной гряды 140 см.

РУП «НПЦ НАН Беларуси по механизации сельского хозяйства» и ГНУ «ЦБС НАН Беларуси» предложили и апробируют технологию возделывания «земляной груши» на грядах шириной 1,5 м в два и три рядка с междурядьями 75 и 42 см.

В статье рассмотрена схема посадки топинамбура 132×35+35+35x30 см по этой схеме расстояние между внутренними обрезами колес кормоуборочного комплекса составляет 169 см. Этого пространства вполне достаточно для размещения четырех рядков с междурядьями 35 см. Следует подчеркнуть, что подобная схема размещения является приемлемой и для использования машин при уборке клубней.

Использование машин для отвоза зеленой массы при вышеуказанной схеме посадки не вызывает деформацию гряды.

Отмечено, что урожайность топинамбура в значительной мере зависит от ширины междурядий. Разработаны схемы посадки клубней с учетом ходовых просветов машин, используемых при уборке как зеленой массы, так и клубней. Описаны оригинальные конструкции машин, применяемые для уборки топинамбура.

Цель данных исследований - разработка схемы посадки топинамбура для обеспечения движения по полю комбайна, убирающего зеленую массу и транспортного агрегата занятого на ее отвозке без травмирования клубней топинамбура в грядах и разработка оригинальных схем машин для уборки клубней топинамбура. способных качественно и без потерь убирать его.
\end{abstract}

Ключевые слова: топинамбур, технологии, оригинальная конструкция, машина, междурядье, сепарация, урожайность, элеватор, очиститель. бункер, транспортер.

Актуальность проблемы. Топинамбур долгие годы рассматривался как кормовая культура, однако анализ результатов последних научных исследований показал, что это культура комплексного использования. Прежде всего - это ценное пищевое растение. Благодаря уникальному биохимическому составу клубней, сухой порошок из них является хорошей биологически активной добавкой во многие продукты питания.

Топинамбур является также ценным сырьем для технической переработки и производства биоэтанола. В настоящее время рядом ведущих научно-исследовательских институтов и учреждений высшего образования проводятся научно исследовательские работы по разработке технологий возделывания топинамбура в бороздах, на грядах и разрабатываются системы машин для его возделывания. Особые требования предъявляются к машинам для уборки клубней топинамбура, которым необходимо разрушить почвенный пласт и корневую часть топинамбура, отсепарировать почву, отделить клубни от столонов, удалить стебли.

Анализ последних исследований. Общепринятая технология возделывания топинамбура на гребнях с междурядьями 70 см не всегда обеспечивает нормальные условия для его роста и развития из-за узких междурядий, не позволяющих обеспечить необходимое питание растений. 
В Московской области накоплен опыт выращивания топинамбура по широкорядной технологии со схемой посадки $(125+15)$ см. В этом случае из двух рядом расположенных гребней формируют одну гряду шириной $140 \mathrm{~cm}$. На грядах исключается повреждение гнезд колесами тракторов, поддерживается оптимальный режим влажности, практически не наблюдается задыхание клубней, увеличивается их число в гнезде и масса. При этой технологии удлиняется период ухода за растениями и значительно снижается засоренность посадок, возрастает урожайность топинамбура, существенно улучшаются условия комбайновой уборки (на $20-40 \%$ снижается количество поступающей в комбайн почвы) [1].

В исследованиях, проведенных В.И. Старовойтовым [2], установлено, что общепринятая технология возделывания топинамбура на гребнях с междурядьями 70 (75) см не обеспечивает нормальные условия для роста и развития топинамбура, особенно во влажные годы, что приводит к снижению урожая или полной его гибели. С их точки зрения для топинамбура наиболее перспективно использование грядовой технологии с шириной гряды 140 см. Выращивание топинамбура по грядовой технологии возможно со схемами посадки 140, 110+30, 135+15 и $110+15+15$ см.

На этих грядах исключается повреждение гнезд топинамбура колесами тракторов, поддерживается оптимальный режим влажности, практически не наблюдается задыхание клубней, увеличивается число клубней в гнезде и их масса. В предлагаемых технологиях удлиняется период ухода за растениями и значительно снижается засоренность посадок. Урожайность топинамбура при грядовой технологии возделывания возрастает на 10 - 26\% по сравнению с гребневой посадкой.

В более поздних исследованиях Старовойтов В.И., Старовойтова О.А., Манохина А.А. [3] еще раз подтвердили преимущества грядовой технологии. По их мнению посадка топинамбуры с междурядьями 70 см для промышленного возделывания топинамбура не пригодна, поскольку имеет ряд недостатков. При уборке зеленой массы летом-осенью используемый транспорт «закатывает» и уплотняет почву в гребнях. Клубненосный пласт плохо разделывается и сепарируется из-за большого размера клубневых гнезд. В результате комбайновая уборка связана с потерями до 40 \% клубней.

В результате проведенных в Республике Беларусь исследований установлено, что ходовые системы кормоуборочной техники оказывают существенное деформирующее влияние на гребни. Анализ ходовых систем кормоуборочной техники показал, что передние колеса УЭС-2$250 \mathrm{~A}$, на котором навешен кормоуборочный комбайн КГ - 6 имеют ширину следа 75 см, в результате чего колеса идут по вершине гребня и уплотняют боковые стенки. Помимо этого, ширина колеи у прицепа ПИМ - 40 равна 200 см, что также ведет к дополнительному уплотнению почвы в гребне при отвозке зеленой массы.

В результате прохода уборочного агрегата высота гребней уменьшается с 25 см до $5 \mathrm{~cm}$.

Данные полевых измерений показывают, что твёрдость почвы в интервале $0-5$ см в деформированных гребнях возросла в 2,7 раза. Особенно сильное уплотнение почвы отмечено в горизонте 5 - $10 \mathrm{~cm}$. Измерение твёрдости показало, что этот показатель в деформированных гребнях в 10 раз больше, чем в контрольном варианте, а в интервале 15 - 20 см твердость возросла с 6 до 12,5 МПа. С увеличением расстояния от вершины гребня твёрдость почвы возрастает в обоих вариантах, однако различия становятся значительно меньшими.

Уплотнение почвы повлекло увеличение её влажности. Максимальная влажность почвы $12,5 \%$ отмечена в деформированном гребне на глубине 5 - 10 см, что на 1,5\% выше, чем у недеформированного гребня.

Проведенный анализ на травмированность клубней топинамбура показал, что в недеформированном гребне клубни не имеют повреждений, а в деформированных гребнях доля не поврежденных клубней составила только 54\%. В деформированном гребне было отмечено наличие поврежденных клубней 16\%, загнивших и потемневших $8 \%$ и с микроповреждениями $22 \%$. В недеформированном гребне клубней с такими дефектами не обнаружено. В результате этого исследователи пришли к выводу, что ширина междурядий 70 см не удовлетворяет агротехническим требованиям возделывания топинамбура [4].

РУП «НПЦ НАН Беларуси по механизации сельского хозяйства» и ГНУ «ЦБС НАН Беларуси» предложили и апробируют технологию возделывания «земляной груши» на грядах шириной 1,5 м в два и три рядка с междурядьями 75 и 42 см [5].

Для возделывания, уборки и послеуборочной переработки топинамбура по предлагаемой технологии научно-практическим центром разработана и подготовлена к постановке на производство следующая система машин: грядоделатель навесной ГН-1 - для нарезки и формирования гряд шириной 1,5 м и высотой $15-20$ см, культиватор грядовый КГ-1 - для обработки посадок топинамбура с междурядьями 42 и 75 см на грядах шириной $1,5 \mathrm{M}$, сажалка грядовая ременного типа СГР-1 - для посадки клубней топинамбура и картофеля в гряду в три рядка с междурядьями 42 см и в два рядка с междурядьями 75 см, комбайн прицепной КГУ-1+ адаптер АУТ-1 - для уборки клубней топинамбура, возделываемых на грядах 
шириной 1,5 м; линия для послеуборочной доработки, предпосадочной и товарной подготовки клубней топинамбура, включающая: бункер приемный, транспортер перегрузочный, машину калибровочную, машину моечную, стол переборочный, конвейер подсушивающий, машину фасовочную, транспортер загрузочный, наполнитель контейнеров .

Уборка клубней топинамбура один из наиболее трудоемких процессов в технологии возделывания этой культуры, на ее долю приходится $60-70 \%$ всех затрат. При уборке клубней возможны четыре способа:

1 - выкапывают клубни картофелекопателем с последующим подбором топинамбура вручную. Трудозатраты при этом способе составляют 280 - 320 чел-часов на 1 га.

Элеваторы картофелекопателя недостаточно эффрективно разрушают почвенный пласт и корневую часть топинамбура. Кроме того, недостаточная сепарирующая поверхность рабочих органов копателей вызывает повышенные потери (присыпание) клубней до12 - 30\%.

2 - двухфазная уборка. Вначале копателемвалкоукладчиком формируется валок шириной около $60 \mathrm{~cm}$, а затем после подсушки клубни подборщиком-погрузчиком грузят в транспортное средство. В результате получается полное отделение почвенных примесей;

3 - уборка копателем-погрузчиком с погрузкой в транспортное средство;

4 - уборка комбайном.

Использование картофелеуборочных комбайнов дает положительные результаты только при уборке клубней ранней весной. Чтобы обеспечить сырьем перерабатывающую промышленность и животноводческую отрасль кормами на весь зимний период топинамбур необходимо убирать в осеннее время. Все дело в том, что после уборки надземной части у топинамбура остается утолщенная часть стебля с мощным корневищем, содержащим сильно развитую корневую систему со столонами и закрепленными на них клубнями. Последние отличаются неправильной формой из-за многочисленных наростов (деток), в лабиринтах которых задерживается значительное количество почвы, поэтому отделить их без повреждений трудно. Кроме того, клубни топинамбура имеют прочную связь со столонами и оторвать их обычными рабочими органами невозможно.

Попытки применить картофелеуборочные комбайны для уборки клубней топинамбура в осеннее время не привели к желаемым результатам. Они плохо разрушают корневую систему (гнезда), в которых находятся клубни топинамбура. Около 45\% их вместе с корневой системой выбрасывается на поле ботвоудаляющим устройством [8].
В ВИСХОМе были проведены исследования по изысканию рабочих органов, которые могли бы интенсифицировать процесс отделения клубней от стебля и улучшить сепарацию почвы на элеваторах уборочных машин [9]. С этой целью на базе однорядного картофелеуборочного комбайна Л-601 изготовлен макетный образец машины для уборки топинамбура (см. рис. 1).

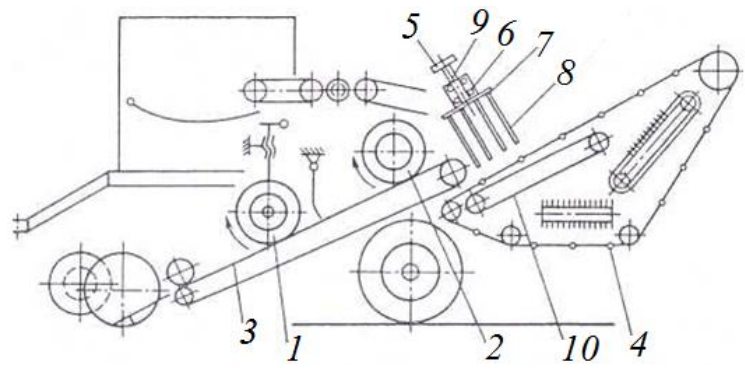

Рис. 1. Схема макетного образца машины для уборки топинамбура

В схему комбайна дополнительно вписаны шнеки 1 и 2 с правой и левой навивками, размещенные над первым сепарирующим элеватором 3. За ним над редкопрутковым транспортером 4 находится комкоразрушающее устройство 5, выполненное в виде установленных в вертикальнопродольной плоскости встречно-вращающихся решетчатых роторов 6. Их поверхность образована из консольно закрепленных на дисках 7 прутков 8, направленных свободными концами вниз в сторону транспортера 4 . Диск 7 смонтирован на консольном валу 9, кинематически связанном через ременную передачу с механизмом привода. Роторы 6 установлены под углом к транспортеру 4. Угол может регулироваться в зависимости от условий уборки. За элеватором 3 сходится второй элеватор 10, размещенный внутри транспортера 4.

При движении машины по полю подкопанный лемехами клубненосный пласт поступает на первый элеватор 3, где происходит его первичная сепарация. При встрече со шнеком 1, имеющим правую навивку пласт смещается на правую половину элеватора, при этом происходит крошение почвенных комков и очистка клубней от почвы. Затем под воздействием шнека 2 имеющим левую навивку движение вороха снова изменяется, что влечет за собой интенсивное перемешивание его слоев, перетирание почвенных комков, сепарацию почвы и частичное отделение клубней от столонов.

Предварительно отсепарированный и сформированный ворох подается полотном первого элеватора 3 на комкоразрушающее устройство 5 . Клубни, почвенные комки и растительность при сходе с первого элеватора 3 имеют различные по 
высоте и дальности траектории движения, поэтому они контактируют с поверхностью одного из роторов 6 практически по всей длине прутков, чем обеспечивается равномерная его загрузка и эфффективная работа.

При встрече с активной решеткой ротора 6, за счет касательных ударных воздействий, происходит разрушение наименее прочных комков и выделение корневой части топинамбура путем отряхивания почвы из межклубневого пространства. Свободные клубни и раздробленные комки почвы при изменении направления движения под воздействием ротора 6 прокатываются по его поверхности и, пройдя зазор между прутками, поступают во внутреннюю полость ротора 6, где, продолжая контактировать с его поверхностью, постепенно скатываются вниз. Основная масса вороха прижимается к поверхности ротора 6 и увлекается им во вращение. Происходит активное растаскивание и рассредоточение компонентов вороха, особенно растительных примесей.

При попадании в узкий створ между роторами ворох подвергается двухстороннему сжимающему воздействию прутков, в результате почвенные комки разрушаются, а стеблевая масса и корневища разламываются. Редкопрутковый транспортер выносит оставшиеся стебли и корневища за пределы машины, а корни, попадая на второй элеватор 10, совершают путь, аналогичный движению клубней картофеля на комбайне Л-601.

Уборка 18 га топинамбура показала следующие результаты: полнота сбора 97\%, повреждение клубней до 6\%, чистота клубней в таре $91 \%$. В настоящее время, на базе рабочих органов, обеспечивающих разделку клубненосного гнезда и разрушение комков почвы, разрабатывается двухрядная машина для уборки топинамбура, выращиваемого по широкорядной технологии.

Цель исследований. Цель данных исследований - разработка схемы посадки топинамбура для обеспечения движения по полю комбайна, убирающего зеленую массу и транспортного агрегата занятого на ее отвозке без травмирования клубней топинамбура в грядах и разработка оригинальных схем машин для уборки клубней топинамбура. способных качественно и без потерь убирать его.

Методический подход к исследованиям. Анализ разработанных технологий по возделыванию топинамбура показывает, что не была учтена одна особенность этой культуры, а, именно, что ее уборку необходимо проводить раздельным способом, сначала необходимо убрать надземную массу для хозяйственного использования, а затем клубни.

Обобщая данные выполненных исследований, следует отметить, что при указанных схемах посадки, ходовые системы кормоуборочных ма- шин будут разрушать гряды и травмировать клубни, что недопустимо по агротехническим требованиям.

Результаты исследований. В Белорусском государственном аграрном техническом университете (БГАТУ) разработана схема посадки клубней топинамбура под конкретную кормоуборочную машину КВК 8060 «ПАЛЕССЕ FS 8060» [6].

Графическое изображение траектории движения маши по полю при уборке зеленой массы топинамбура представлено на рис. 2.

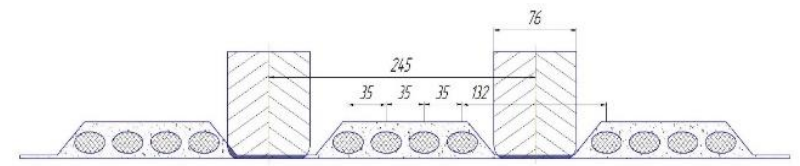

a)

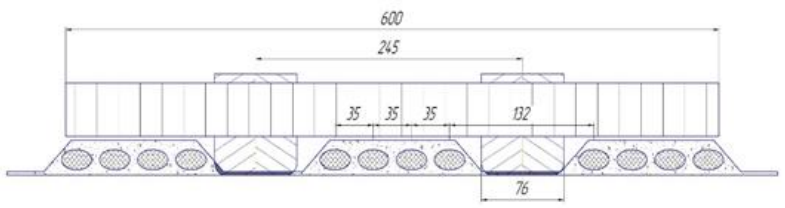

б)

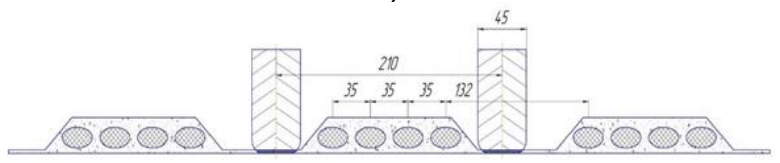

в)

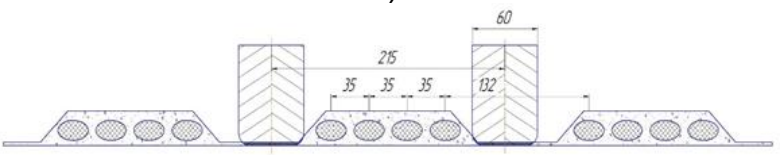

Рис.2. Траектория движения кормоуборочной техники по полю при уборке зеленой массы топинамбура:

а) траектория движения кормоуборочного комплекса КВК 8060 «ПАЛЕCCE FS 8060»;

б) траектория движения трактора Беларус 1221;

в) траектория движения прицепа - ПС - 60

Анализ представленной схемы показал, что при использовании современных высокопроизводительных машин для уборки надземной массы топинамбура оптимальной будет схема посадки $132 \times 35+35+35 \times 30$ см. Как видно из схемы, расстояние между внутренними обрезами колес кормоуборочного комплекса составляет 169 см. Этого пространства вполне достаточно для размещения четырех рядков с междурядьями 35 см. Следует подчеркнуть, что подобная схема размещения является приемлемой и для использования машин при уборке клубней.

Ширина следа передних колес кормоуборочного комплекса равна 76 см. Из схемы видно, что защитная зона межу колесом трактора и крайним гребнем в ленте составляет 17 см, что устраняет нарушение целостности гребня колесом. 
Жатка для уборки грубостебельных культур кормоуборочного комплекса имеет ширину захвата 6 м. При данной схеме посадки за один проход кормоуборочного комплекса зеленая масса будет убрана с трех полос (см. рис. 2). Однако точное вождение в данной ситуации возможно только с помощью GPS.

Использование машин для отвоза зеленой массы при вышеуказанной схеме посадки не вызывает деформацию гряды.

В БГАТУ разработана оригинальная схема машины для уборки клубней топинамбура, позволяющая интенсифицировать процесс разрушения почвенного пласта и корневой части топинамбура [7] (рис. 3, а - машина для уборки клубней топинамбура, вид сбоку; б - разрез А-А; в - вид Б).

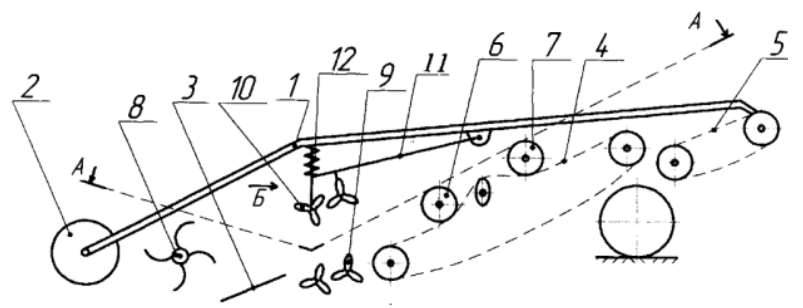

a)

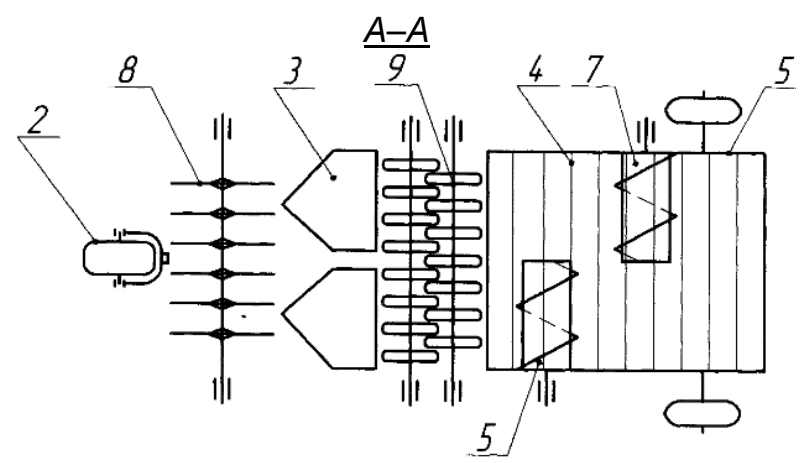

б)

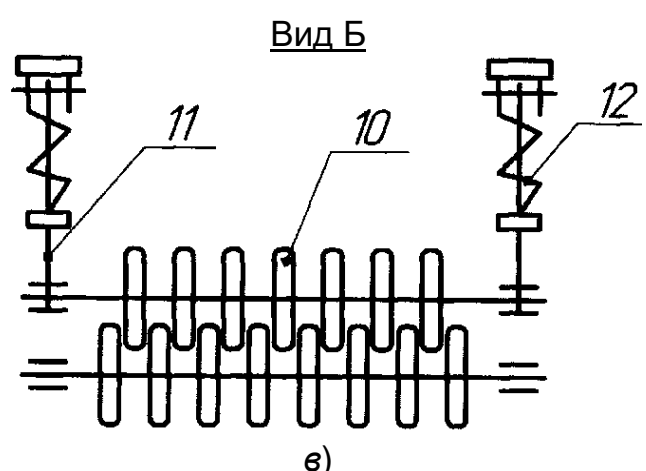

Рис. 3. Машина для уборки клубней топинамбура

Машина для уборки клубней топинамбура содержит раму 1 , копирующий каток 2 , подкапывающие лемехи 3, первый 4 и второй 5 сепарирующие элеваторы, шнеки с правой 6 и левой 7 навивками, размещенные над первым 4 сепарирующим элеватором.

Перед подкапывающими лемехами 3 установлены пальцевые роторы 8 с возможностью вращения в вертикальной плоскости, а между подкапывающими лемехами 3 и первым 4 сепарирующим элеватором установлено комкоразрушающее устройство, выполненное из нижних 9 и верхних 10 рядов фоигурных дисков с возможностью вращения навстречу друг другу, при этом их размеры и расположение в рядах обеспечивают вхождение фригурных дисков последующего ряда в пространство между дисками предыдущего ряда, а ряды верхних 10 фигурных дисков установлены на рамке 11 и подпружинены пружинами сжатия 12 с возможностью перемещения по вертикали.

Машина для уборки клубней топинамбура работает следующим образом.

Копирующий каток 2 наклоняет стебель топинамбура и прижимает его к земле. Пальцевые роторы 8, за счет своего вращения, разрезают почвенный пласт и разрушают корневище топинамбура. Образованный при этом пласт подкапывается лемехами 3 и подается на комкоразрушающее устройство, где за счет вращения нижних 9 рядов фигурных дисков и прижимающихся к почвенному пласту пружинами 12 верхних 10 рядов фигурных дисков, установленных на рамке 11 происходит интенсивное разрушение почвенного пласта и корневой части топинамбура.Далее разрыхленная почва, клубни и стебли топинамбура поступают на первый 4 сепарирующий элеватор, где с помощью шнеков с правой 6 и левой 7 навивками происходит дальнейшее разрушение комков и отрыв клубней от стебля. Окончательная сепарация почвы происходит на втором 5 ceпарирующем элеваторе.

Установка пальцевых роторов перед подкапывающими лемехами позволяет разрезать почвенный пласт и разрушить корневище топинамбура, что облегчает работу последующих рабочих органов, а наличие комкоразрушающего устройства, выполненного из нижних и верхних рядов фигуурных дисков с возможностью вращения навстречу друг другу, интенсифицирует процесс сепарации почвы.

В БГАТУ предложена оригинальная машина (комбайн) для уборки клубней топинамбура в которой применен активный метод отделения клубней топинамбура от столонов [10] (рис. 4: а - машина для уборки клубней топинамбура, вид сбоку; б - машина для уборки клубней топинамбура, вид сверху; в - вид по стрелке А).

Машина для уборки клубней топинамбура содержит копирующий каток 1, состоящий из двух катков, закрепленных на одной оси, подкапывающий лемех 2, комкоразрушающее устройство, установленное над передней частью первого 
сепарирующего элеватора 3, состоящее из прижимных ремней 4, приводных 5 , натяжных 6 и прижимных 7 роликов, очесывающего устройства, выполненного в виде вращающихся валов 8 с закрепленными на них пальцами 9. Машина содержит также поперечный транспортер 10, бунке для сбора клубней 11 и второй сепарирующий элеватор 12.

Машина для уборки клубней топинамбура работает следующим образом.

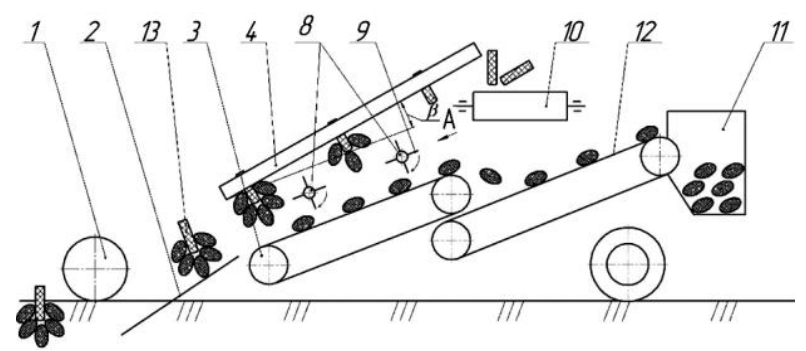

a)

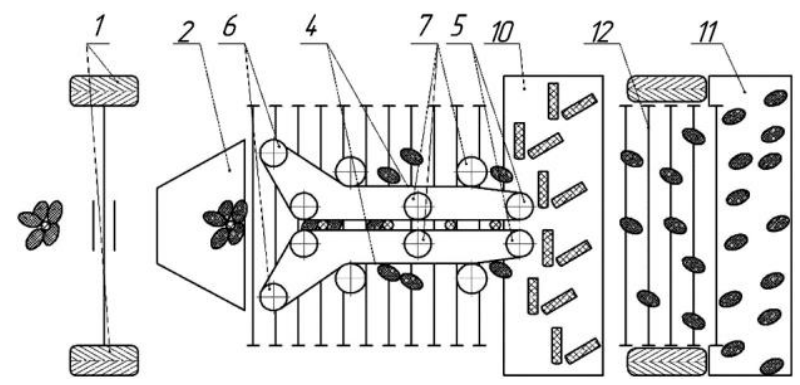

б)

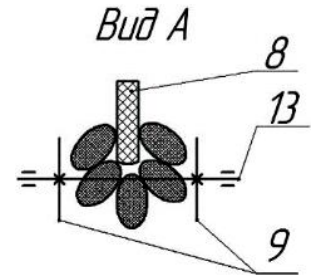

в)

Рис. 4. Машина для уборки клубней топинамбура

Копирующий каток 1 копирует профиль грядки. Подкапывающий лемех 2 подкапывает почвенный пласт, включающий гнезда топинамбура 13, который подается на первый элеватор 3 , где почвенный пласт крошится, а гнезда топинамбура 13 , состоящие из стеблей растения и соединенных с ними столонами клубней топинамбура направляются к комкоразрушающему устройству, стебли захватываются прижимными ремнями 4, у которых скорость движения одного ремня равна скорости движения первого сепарирующего элеватора, а второго - на 20\% меньше скорости первого приводного ремня, удерживаются ими с помощью приводных 5, натяжных 6 и прижимных 7 роликов, приподнимаются над первым элевато- ром 3 за счет угла $\beta$, равного $25-30^{0}$ и очесывающим устройством, выполненным в виде вращающихся валов 8 с закрепленными на них пальцами 9, происходит отрыв клубней топинамбура от столонов. За счет разной скорости движения прижимных ремней 4 гнезда топинамбура 13 во время движения поворачиваются, обеспечивая обрыв клубней со всех сторон стеблей.

Далее стебли топинамбура поступают на поперечный транспортер 10 и выносятся им за пределы машины.

На втором элеваторе 12 происходит дальнейшее разрушение комков и сепарация почвы, а клубни топинамбура направляются в бункер 11 для сбора клубней.

За счет захватывания стеблей растения прижимными ремнями и приподнимания ими над первым элеватором происходит разрушение почвенного пласта, что облегчает работу очесывающего устройства и интенсифицирует процесс сепарации почвы и отделения клубней топинамбура от столонов.

Выводы. Проанализированы технологии возделывания топинамбура. Отмечено, что его урожайность зависит от ширины междурядий. Разработаны схемы посадки клубней с учетом ходовых просветов машин, используемых при уборке как зеленой массы и клубней.

Разработана схема посадки топинамбура под кормоуборочную машину КВК 8060 «ПАЛЕCCE FS 8060», позволяющая минимизировать потери клубней за счет их раздавливания.

Предложенные в статье оригинальные схемы картофелекопателя и картофелеуборочного комбайна позволят интенсифицировать процесс разрушения почвенного пласта и корневой части топинамбура и снизить потери клубней при уборке.

\section{Литература}

1. Технология и комплекс машин для производства топинамбура / Э.С. Рейнгарт [и др.]. // Тракторы и сельскохозяйственные машины. - 2003. - № 11. - С.30 - 31.

2. Старовойтов, В.И. Технология и механизация возделывания топинамбура / В.И. Старовойтов // Материалы I междунар. науч.-практич. конф. «Растительные ресурсы для здоровья человека (возделывание, переработка, маркетинг)», 23-27 сентября 2002г. - М., Сергиев-Пасад, 2002. - С.435 - 439.

3. Старовойтов, В.И. Особенности технологии и машины для возделывания топинамбура / В.И. Старовойтов, О.А. Старовойтова, А.А. Манохина // Сельский механиз. - 2015.- №11. - С. 4 - 5.

4. Влияние кормоуборочной техники на деформацию гребня и травмированность клубней 
при уборке надземной массы топинамбура / А.В. Горный [и др.] // Доклады Междунар. науч.технич. конф. «Тракторы, автомобили, мобильные энергетические средства: проблемы и перспективы развития», посвященной 80-летию со дня рождения доктора технических наук, профессора Скотникова Валерия Александровича, 11-14 февраля 2009г. - Минск : БГАТУ. - 2009. - С.183.

5. Яковчик, Н. Перспективный и многофункциональный топинамбур / Н. Яковчик, С. Яковчик / Белорусское сельское хозяйство. - 2018. - № 2 (190). - С.104 - 106.

6. Обоснование ширины междурядий при возделывании топинамбура в промышленной культуре / Н.Н. Романюк [и др]. // Материалы Междунар. науч.- практич. конф. «Экологическое состояние природной среды и научно-практические аспекты современных агротехнологий», 2223 марта 2018г., в 2-х Ч. г. Рязань / отв. ред. Д.В. Виноградов. - Рязань ; Изд-во РГАТУ, 2018. 4.1. - С.342 - 347.

7. Машина для уборки клубней топинамбура: патент 20231 C1 Респ. Беларусь, МПК A 01D 17/06 / Н.Н. Романюк, К.В.Сашко, Д.С.Захарчук, Е.С.Курьян ; заявитель Белорус. гос. аграр. техн. ун-т. - № а20130245; заявл. 25.02.2013; опубл. 30.08.2016 // Афріцыйны бюл. / Нац. цэнтр інтэлектуал. уласнасці. - 2016. - № 4. - С.78.

8. Рейнгарт, Э.С. Машина убирает топинамбур / Э.С. Рейнгарт, Г.П. Варламов, В.А. Рытченко // Сельский механиз. - 2003. - № 8. - С. 14-16.

9. Варламов, Г.П. Технология механизированной уборки клубней топинамбура / Г.П. Варламов, Э.С. Рейнгарт, А.А. Сорокин // Тракторы и сельскохоз. машины. - 1999. - №9. - С.10 - 13.

10. Машина для уборки клубней топинамбура: патент 22746 C1 Респ. Беларусь, МПК А 01D 17/00 , A 01D 33/00 / Н.Н.Романюк, К.В.Сашко, А.В.Горный, Д.Н.Грищенко, С.Ф.Лойко ; заявитель Белорус. гос. аграр. техн. ун-т. - № а 20180232 ; заявл. 05.06.2018; опубл. 30.10.2019 // Афріцыйны бюл. / Нац. цэнтр інтэлектуал. уласнасці. - 2019. - № 5. - С.43.

\section{References}

1. Tekhnologiya i kompleks mashin dlya proizvodstva topinambura / E.S. Reyngart [i dr.]. // Traktory i sel'skokhozyaystvennyye mashiny. 2003. - № 11. - S.30 - 31.

2. Starovoytov, V.I. Tekhnologiya i mekhanizatsiya vozdelyvaniya topinambura / V.I. Starovoytov // Materialy I mezhdunar. nauch.-praktich. konf. «Rastitel'nyye resursy dlya zdorov'ya cheloveka (vozdelyvaniye, pererabotka, marketing)», 23-27 sentyabrya 2002g. - M., SergiyevPasad, 2002. - S.435 - 439.

3. Starovoytov, V.I. Osobennosti tekhnologii i mashiny dlya vozdelyvaniya topinambura / V.I. Starovoytov, O.A. Starovoytova, A.A.Manokhina // Sel'skiy mekhanizator. - 2015. - №11. - S. 4 - 5.

4. Vliyaniye kormouborochnoy tekhniki na deformatsiyu grebnya i travmirovannost' klubney pri uborke nadzemnoy massy topinambura / A.V. Gornyy [i dr.] // Doklady Mezhdunar. nauch.-tekhnich. konf. «Traktory, avtomobili, mobil'nyye energeticheskiye sredstva: problemy i perspektivy razvitiya», posvyashchennoy 80-letiyu so dnya rozhdeniya doktora tekhnicheskikh nauk, professora Skotnikova Valeriya Aleksandrovicha, 11-14 fevralya 2009g. Minsk: BGATU. - 2009. - S.183.

5. Yakovchik, N. Perspektivnyy i mnogofunktsional'nyy topinambur / N. Yakovchik, S. Yakovchik / Belorusskoye sel'skoye khozyaystvo. 2018. - № 2 (190). - S.104 - 106.

6. Obosnovaniye shiriny mezhduryadiy pri vozdelyvanii topinambura v promyshlennoy kul'ture / N.N. Romanyuk [i dr]. // Materialy Mezhdunar. nauch.- praktich. konf. «Ekologicheskoye sostoyaniye prirodnoy sredy i nauchno-prakticheskiye aspekty sovremennykh agrotekhnologiy», 22-23 marta 2018g., v 2-kh CH. g. Ryazan' / otv. red. D.V. Vinogradov. - Ryazan'; Izd-vo RGATU, 2018. CH.1. - S.342 - 347.

7. Mashina dlya uborki klubney topinambura : patent 20231 C1 Resp. Belarus', MPK A 01D 17/06 / N.N. Romanyuk, K.V.Sashko, D.S.Zakharchuk, Ye.S.Kur'yan ; zayavitel' Belorus. gos. agrar. tekhn. un-t. - № a20130245; zayavl. 25.02.2013; opubl. 30.08.2016 // Afitsyyny byul. / Nats. tsentr intelektual. ulasnastsi. - 2016. - № 4. - S.78.

8. Reyngart, E.S. Mashina ubirayet topinambur / E.S. Reyngart, G.P. Varlamov, V.A. Rytchenko // Sel'skiy mekhanizator. - 2003. - № 8. - S. 14-16.

9. Varlamov, G.P. Tekhnologiya mekhanizirovannoy uborki klubney topinambura / G.P. Varlamov, E.S. Reyngart, A.A. Sorokin // Traktory i sel'skokhozyaystvennyye mashiny. - 1999. - №9. - S.10 - 13.

10. Mashina dlya uborki klubney topinambura : patent 22746 S1 Resp. Belarus', MPK A 01D 17/00, A 01D 33/00 / N.N.Romanyuk, K.V.Sashko, A.V.Gornyy, D.N.Grishchenko, S.F.Loyko ; zayavitel' Belorus. gos. agrar. tekhn. un-t. - № a 20180232 ; zayavl. 05.06.2018; opubl. 30.10.2019// Afitsyyny byul. / Nats. tsentr intelektual. ulasnastsi. 2019. - № 5. - S.43. 
Анотація

\section{Технології обробітку топінамбура}

\section{М.М. Романюк, К.В. Сашко, О.В. Горний, К.Г.Романюк}

У статті проаналізовані технології обробітку топінамбура в Республіці Білорусь і Російській Федерації. Топінамбур довгі роки розглядався як кормова культура, проте аналіз результатів останніх наукових досліджень показав, що це культура комплексного використання. Передусім - це цінна харчова рослина. Завдяки унікальному біохімічному складу бульб, сухий порошок з них $є$ якісною біологічно активною добавкою в велику кількість продуктів харчування.

Топінамбур є також цінною сировиною для технічної переробки і виробництва біоетанолу.

Загальноприйнята технологія обробітку топінамбура на гребенях з міжряддями 70 см не завжди забезпечує нормальні умови для його зростання і розвитку із за вузьких міжрядь, та не дозволяє забезпечити необхідне живлення. У дослідженнях, проведених В. І. Старовойтовым, встановлено, що загальноприйнята технологія обробітку топінамбура на гребенях з міжряддями 70 (75) см не забезпечує нормальні умови для зростання і розвитку топінамбура, особливо у вологі роки, що призводить до зниження урожаю або його повної загибелі. Із їх точки зору для топінамбура найбільш перспективне використання грядкової технології з шириною гряди $140 \mathrm{~cm}$

РУП «НПЦ НАН Білорусі по механізації сільського господарства» і ГНУ «ЦБС НАН Білорусі» запропонували і апробовують технологію обробітку «земляної груші» на грядах шириною 1,5 м в два і три рядки з міжряддями 75 і $42 \mathrm{~cm}$

У статті розглянута схема посадки топінамбура $132 \times 35+35+35 \times 30$ см за цією схемою відстань між внутрішніми обрізами коліс кормозбирального комплексу складає 169 см Цього простору цілком вистачає для розміщення чотирьох рядків з міжряддями 35 см. Слід підкреслити, що подібна схема розміщення $€$ прийнятною і для використання машин при прибиранні бульб.

Використання машин для вивезення зеленої маси при вищезгаданій схемі посадки не викликає деформацію гряди.

Відмічено, що врожайність топінамбура значною мірою залежить від ширини міжрядь. Розроблені схеми посадки бульб з урахуванням ходових просвітів машин, використовуваних при прибиранні як зеленої маси, так і бульб. Описані оригінальні конструкції машин, застосовані для прибирання топінамбура.

Мета цих досліджень - розробка схеми посадки топінамбура для забезпечення руху по полю комбайна, що прибирає зелену масу і транспортного агрегату зайнятого на ії̈ вивезення без травмування бульб топінамбура в грядах і розробка оригінальних схем машин для прибирання бульб топінамбура, здатних якісно і без втрат прибирати його.

Ключові слова: топінамбур, технології, оригінальна конструкція, машина, міжряддя, сепарація, врожайність, елеватор, очисник, бункер, транспортер.

Abstract

\section{Topinambur cultivation technologies}

\section{M.M. Ramaniuk, K.U. Sashko, A.U. Horny, K.R. Ramaniuk}

The cultivation technologies of topinambur have been analyzed in the article. Topinambur has been considered as a forage crop for many years, but analysis of recent scientific studies has shown that it is a culture of integrated use. First of all, it is a valuable food plant. Due to the unique biochemical composition of tubers, the dry powder of them is a good biologically active supplement to many food products.

Topinambur is also a valuable raw material for the technical processing and production of bioethanol.

Generally accepted cultivation technology of topinambur on ridges with $70 \mathrm{~cm}$ row-spacing does not always provide normal conditions for its growth and development due to narrow row-spacing, which does not allow to provide the necessary plant nutrition. In studies, conducted by V.I. Starovoitov, it is established that the generally accepted cultivation technology of topinambur on ridges with row-spacing of $70(75) \mathrm{cm}$ does not provide normal conditions for growth and development of topinambur, especially in wet years, which leads to a yield depression or complete destruction. In their view, the use of ridge technology with a ridge width of 140 $\mathrm{cm}$ for topinambur is most promising.

RUE "RPC NAS of Belarus on Agricultural mechanization" and SSI "CBG NAS of Belarus" have proposed and are now testing the cultivation technology of "earth pear" on ridges 1.5 meters wide in two and three rows with row spacing of 75 and $42 \mathrm{~cm}$. 
The scheme of topinambur planting $132 \times 35+35+35 \times 30 \mathrm{~cm}$ is considered in the article. Under this scheme, the distance between internal cuts of wheels of a forage harvesting complex is $169 \mathrm{~cm}$. This space is quite enough for placing four rows with spacing of $35 \mathrm{~cm}$. It should be stressed, that such a scheme of layout is also acceptable for using machines while harvesting the tubers.

The use of green mass removal machines using the above-mentioned scheme does not cause the ridge deformation.

It is noted that the yield of topinambur largely depends on the width of the row spacing. The schemes for planting tubers have been developed, taking into account the running clearance of machines used for harvesting both green mass and tubers. Original designs of machines used for topinambur harvesting are described.

The purpose of these studies is to develop a scheme of topinambur planting to provide the movement of a harvesting machine on the field that harvests the green mass, and a hauling unit used for its transportation without bruising of topinambur tubers in ridges, and the development of original schemes of machines for topinambur tubers harvesting, capable for high-quality and lossless harvesting.

Keywords: topinambur, technologies, original design, machine, segregation, yield, elevator, cleaning machine, tanker, conveyer.

\section{Бібліографічне посилання/ Bibliography citation: Harvard}

Ramaniuk M.M., Sashko K.U., Horny A.U. and Ramaniuk K.R. (2020). Topinambur cultivation technologies. Engineering of nature management, (1(15), pp. 44 - 52.

Подано до редакції / Received: 12.01.2020 